\title{
Microelectrode studies of seasonal oxygen uptake in a coastal sediment: role of molecular diffusion
}

\author{
Hanne Rasmussen*, Bo Barker Jørgensen \\ Department of Ecology and Genetics, University of Aarhus, Ny Munkegade, DK-8000 Aarhus C, Denmark
}

\begin{abstract}
Oxygen uptake rates and microdistributions of $\mathrm{O}_{2}$ in sediment of Aarhus Bay, Denmark, were studied over a year. Oxygen uptake was determined in the laboratory by 3 methods: (a) total $\mathrm{O}_{2}$ uptake in closed cores, (b) $\mathrm{O}_{2}$ flux through the diffusive boundary layer and (c) $\mathrm{O}_{2}$ consumption within the oxic surface zone. The $\mathrm{O}_{2}$ consumption rates in the oxic surface layer, calculated from (b) and (c) using molecular diffusion coefficients of $\mathrm{O}_{2}$, closely agreed and accounted for $70 \%$ of the total $\mathrm{O}_{2}$ uptake. The $\mathrm{O}_{2}$ uptake rates strongly depended on in situ $\mathrm{O}_{2}$ concentrations in the overlying seawater, which in the bay varied from $100 \%$ air saturation during winter to $23 \%$ during summer. The potentially higher $\mathrm{O}_{2}$ respiration during the summer months was counteracted by a lower $\mathrm{O}_{2}$ concentration in the bottom water, which led to a small seasonal variation in $\mathrm{O}_{2}$ uptake. Depth of the oxic sediment zone reached $5.1 \mathrm{~mm}$ during winter, narrowed down rapidly to a few $\mathrm{mm}$ upon settling of a spring phytoplankton bloom, and was only $1.2 \mathrm{~mm}$ during summer. Modeling of $\mathrm{O}_{2}$ consumption from $\mathrm{O}_{2}$ microprofiles showed zero-order kinetics, i.e. constant $\mathrm{O}_{2}$ consumption rates throughout the oxic zone during winter. Enhanced $\mathrm{O}_{2}$ consumption was found at the oxic-anoxic interface during summer, presumably due to reducing solutes which diffused up from anoxic layers. Sediment $\mathrm{O}_{2}$ uptake was impeded by 3 to $5 \%$ during winter and by 12 to $16 \%$ during summer due to transport resistance through the $300 \mu \mathrm{m}$ thick diffusive boundary layer. Results demonstrate the importance of the boundary layer for sediment $\mathrm{O}_{2}$ uptake and its regulation.
\end{abstract}

\section{INTRODUCTION}

Oxygen consumption by marine sediments has been the most widely studied parameter to determine benthic metabolism and organic mineralization. Common techniques for such studies include $\mathrm{O}_{2}$ uptake measurements in laboratory-incubated sediment cores or in situ measurements using benthic flux chambers (e.g. Pamatmat 1971, Smith 1978). In recent years, several studies have also used $\mathrm{O}_{2}$ microelectrode data to determine the diffusive $\mathrm{O}_{2}$ flux (Revsbech et al. 1980b, Reimers \& Smith 1986, Booij 1989, Sweerts et al. 1989, Hofman et al. 1991). The role of $\mathrm{O}_{2}$ respiration by the benthic fauna or of their transport of oxic water deep into the sediment has also been studied, either by

\footnotetext{
- Present address: Laboratory of Environmental Engineering, Aalborg University Center, Sohngårdsholmsvej 57. DK-9000 Aalborg, Denmark
}

directly determining the respiration rate of the faunal community, by calculating their ventilation activity, or by subtracting the diffusive from the total $\mathrm{O}_{2}$ uptake (e.g. Aller 1978, Kristensen 1985, Kanneworff \& Christensen 1986).

The oxic surface zone of coastal sediments is generally a millimeter-thin layer within which intensive respiration takes place. By the use of $\mathrm{O}_{2}$ microelectrodes it is possible to analyze the distribution of $\mathrm{O}_{2}$ within this oxic layer at $<100 \mu \mathrm{m}$ resolution and thus experimentally to analyze the mechanisms of $\mathrm{O}_{2}$ consumption in order to understand its regulation. Based on measured microgradients of $\mathrm{O}_{2}$, depth distribution of aerobic respiration. within the oxic zone can be calculated by simple models (e.g. Revsbech et al. 1986, Nielsen et al. 1990). A diffusive boundary layer (DBL) of 0.2 to $1 \mathrm{~mm}$ thickness has furthermore been found in the water immediately over the sediment surface from such microgradient measurements 
(Jørgensen \& Revsbech 1985, Jørgensen \& Des Marais 1990, Gundersen \& Jorgensen 1990, 1991). Oxygen and other dissolved compounds, which exchange across the sediment-water interface, move rapidly through this DBL by molecular diffusion along a nearlinear concentration gradient. This diffusion flux can therefore be calculated directly from $\mathrm{O}_{2}$ microgradients measured in the DBL.

In the present study, we combined measurements of the total $\mathrm{O}_{2}$ consumption in incubated sediment cores with 2 methods for studying the diffusive $\mathrm{O}_{2}$ uptake: flux calculations through the DBL and modeling of $\mathrm{O}_{2}$ consumption rates within the oxic surface zone. Among the goals of the study was to determine how much of the total $\mathrm{O}_{2}$ uptake was due to diffusion through the DBL and consumption in the oxic surface layer Regulation of $\mathrm{O}_{2}$ uptake by varying $\mathrm{O}_{2}$ concentrations in the overlying water and by diffusion impedance due to the DBL were also studied.

\section{MATERIALS AND METHODS}

Study site. Seasonal oxygen uptake was studied in fine-grained sediment from 1 station $\left(56^{\circ} 09.1^{\prime} \mathrm{N}\right.$, $10^{\circ} 19.2^{\prime} \mathrm{E}$ ) in central Aarhus Bay, Denmark, at $15 \mathrm{~m}$ water depth. Samples were taken from onboard ship 24 times during the period March 1988 to May 1989 and were carefully transported to the laboratory in Aarhus for incubation within 3 to $5 \mathrm{~h}$. Four other stations at 13 to $33 \mathrm{~m}$ water depth in southern Kattegat, situated in the Baltic Sea - North Sea transition area, were studied onboard ship during 2 cruises with RV 'Gunnar Thorson' (Danish National Agency for Environmental Protection).

Sediment sampling and incubation. Sediment was collected by a Haps corer (Kanneworf \& Nicolaisen 1973). Only cores with a visibly undisturbed sediment surface and clear overlying water were accepted. Subcores of $5 \mathrm{~cm}$ diameter were taken in $20 \mathrm{~cm}$ long Plexiglas tubes for oxygen studies and other determinations. Twenty liters of seawater was taken with a Niskin bottle 0.5 to $1 \mathrm{~m}$ over the bottom for core incubations. Seawater samples were also taken from the surface and bottom for determination of temperature, salinity, and oxygen.

For each sampling occasion, 6 sediment cores were incubated uncapped, submerged in a dark aquarium containing bottom water from the sampling station. Water in the aquarium was maintained at in situ temperature and continuously flushed with an air $/ \mathrm{N}_{2}$ gas mixture to maintain in situ $\mathrm{O}_{2}$ concentrations over all sediment cores. A rotating, teflon-coated magnet, $3 \times 15 \mathrm{~mm}$, was attached to the inner wall of each tube over the sediment. Magnets rotated at $90 \mathrm{rpm}$, driven by a large, external magnet, and produced a turbulent flow in the cores which was evaluated to be realistic relative to in situ flow velocities in Aarhus Bay observed by underwater video. Cores were preincubated for $2 \mathrm{~h}$ prior to measurements to assure steady-state oxygen distributions in the sediment. At the start of measurements, all cores were open at the top with homogeneously stirred sea water of in situ $\mathrm{O}_{2}$ concentration. Microgradients of $\mathrm{O}_{2}$ were measured, and only then were the cores stoppered for total $\mathrm{O}_{2}$ uptake measurements.

Oxygen microgradients. The $\mathrm{O}_{2}$ distribution was measured by $\mathrm{O}_{2}$ microelectrodes provided with a builtin reference and a guard cathode (Revsbech 1989b). Electrodes had a sensing tip of 5 to $10 \mu \mathrm{m}$ and a linear $\mathrm{O}_{2}$ response within 0 to $100 \%$ air saturation. Velocity sensitivity of the electrodes (i.e. signal increase in flowing vs stagnant water) was $<2-3 \%$, and the $90 \%$ response time was ca $1.5 \mathrm{~s}$. Electrode currents for $0 \%$ and $100 \%$ air saturation of $\mathrm{O}_{2}$ at $20^{\circ} \mathrm{C}$ were 2 to $8 \mathrm{pA}$ and 200 to $300 \mathrm{pA}$, respectively. Linear calibration was done for each $\mathrm{O}_{2}$ profile between the overlying water of known $\mathrm{O}_{2}$ concentration and the anoxic layer within the sediment.

The electrode was attached to a micromanipulator driven by a stepping motor and data were collected directly on a computer. Four $\mathrm{O}_{2}$ profiles were measured in each of 6 cores at random positions. Oxygen measurements were taken at 50 to $200 \mu \mathrm{m}$ depth intervals. In order to position exactly the measured $\mathrm{O}_{2}$ microprofiles relative to the sediment-water interface, and thereby to determine the thickness of the DBL, the sediment and the electrode tip were observed simultaneously under a dissecting microscope.

Diffusive oxygen flux. The diffusive flux, $J_{1}$ of $\mathrm{O}_{2}$ downwards across the sediment-water interface was calculated from the measured $\mathrm{O}_{2}$ microgradients, $\mathrm{dC} / \mathrm{d} z$, through the DBL (Crank 1983, Jørgensen \& Revsbech 1985):

$$
J=-D \mathrm{~d} C / \mathrm{d} z
$$

where $D=$ molecular diffusion coefficient of oxygen, $C=\mathrm{O}_{2}$ concentration, and $z=$ depth $(z=0$ at sedimentwater interface). The flux can also be expressed as the finite shift in $C$ across the DBL:

$$
J=D\left(C_{\mathrm{w}}-C_{0}\right) / z_{\delta}
$$

where $C_{w}=O_{2}$ concentration in the mixed, overlying water, $C_{0}=\mathrm{O}_{2}$ concentration at the sediment-water interface, and $Z_{\delta}=$ the thickness of the effective DBL (cf. Jørgensen \& Revsbech 1985). Values of $D$ were taken from Broecker and Peng (1974) and were recalculated to in situ temperature using the StokesEinstein relation (Li \& Gregory 1974). 
Modeling of oxygen consumption: zero order. Oxygen consumption rates per unit sediment volume in the oxic surface zone were calculated from the measured $\mathrm{O}_{2}$ microprofiles assuming zero-order or first-order consumption kinetics. By zero-order kinetics, the $\mathrm{O}_{2}$ consumption rate was assumed to be independent of depth in the sediment. By first-order kinetics, it was assumed to be proportional to $\mathrm{O}_{2}$ concentration. Reproducibility of $\mathrm{O}_{2}$ microgradients over time showed that these were at steady state.

For zero-order kinetics, the depth-independent removal rate, $R$, of $\mathrm{O}_{2}$ per unit volume of pore water at any given depth in the sediment is at steady state balanced by the supply due to diffusion:

$$
R=D_{\mathrm{S}} \mathrm{d}^{2} C / \mathrm{d} z^{2}
$$

where $D_{\mathrm{S}}=$ the sediment diffusion coefficient (Berner 1980) of $\mathrm{O}_{2}$ and $C=\mathrm{O}_{2}$ concentration in the pore water. Sediment porosity, and thus $D_{\mathrm{S}}$, are assumed to be constant with depth (see below). Eq. (3), which determines the depth distribution of $\mathrm{O}_{2}$ in the sediment, can be solved for $C$ given relevant boundary conditions (Bouldin 1968):

$$
C=\left(R / 2 D_{\mathrm{S}}\right) z^{2}-\left(2 C_{0} R / D_{\mathrm{S}}\right)^{1 / 2} z+C_{0}
$$

The flux of $\mathrm{O}_{2}$ into the sediment is:

$$
J=\left(2 C_{\mathrm{o}} R D_{\mathrm{S}}\right)^{1 / 2}
$$

The total depth of $\mathrm{O}_{2}$ penetration, $z_{\max }$ into the sediment can be found from Eq. (4) by setting $C=0$ :

$$
z_{\max }=\left(2 C_{0} D_{\mathrm{S}} / R\right)^{1 / 2}
$$

By introducing the expression for $J$ (Eq. 5), this equation for $\mathrm{O}_{2}$ penetration is comparable to that used by Revsbech et al. (1980a):

$$
z_{\max }=2 C_{0} D_{\mathrm{S}} \phi / J
$$

where $\phi=$ sediment porosity.

For modeling of zero-order kinetics of $\mathrm{O}_{2}$ consumption, we used the manual curve-fitting appraach described by Nielsen et al. (1990), who found this simple method to yield rates which compared well to those obtained by computer simulation of $\mathrm{O}_{2}$ microelectrode data. By this approach, $\mathrm{O}_{2}$ profiles are visually fitted by one or several parabolas selected from graphs of families of parabolas on transparencies. Each parabola describes a second-order polynomial:

$$
C=a z^{2}+b z+c
$$

where $a, b$, and $c$ are constants. The 2 nd derivative of this polynomial is:

$$
\mathrm{d}^{2} \mathrm{C} / \mathrm{d} z^{2}=2 a
$$

The value of $\mathrm{d}^{2} \mathrm{C} / \mathrm{d} z^{2}$ is thus determined from the $a$ value of the parabola yielding the best fit to the $\mathrm{O}_{2}$ data. Given a value for $D_{\mathrm{S}}$ (see below), the $\mathrm{O}_{2}$ consumption rate, $R$, can then be calculated from Eq. (3).

From the $\mathrm{O}_{2}$ consumption rates per unit volume of sediment, $R_{\mathrm{s}}$ ( $=R \phi$ ), the total oxygen consumption within the $\mathrm{O}_{2}$ zone was determined per unit area by multiplying by the thickness of the oxic zone.

Modeling of oxygen consumption: first-order. The steady state depth distribution with $\mathrm{O}_{2}$ at first-order reaction kinetics is exponential (Bouldin 1968):

$$
C=C_{0} \exp \left(-z /\left(K / D_{\mathrm{S}}\right)^{1 / 2}\right)
$$

where $K$ is a constant describing the rate of $\mathrm{O}_{2}$ consumption per unit volume as a function of $\mathrm{O}_{2}$ concentration. The best fit of $K$ can be found from the measured $\mathrm{O}_{2}$ microgradients. Flux of $\mathrm{O}_{2}$ across the sediment-water interface with first-order kinetics is simply proportional to the $\mathrm{O}_{2}$ concentration:

$$
J=C_{\mathrm{o}}\left(D_{\mathrm{S}} K\right)^{1 / 2}
$$

Modeling of oxygen consumption with DBL. The presence of a diffusive boundary layer is generally evident from measured $\mathrm{O}_{2}$ microgradients, and the sediment-water interface is in many cases evident as a break in slope of the $\mathrm{O}_{2}$ gradient, $\mathrm{d} C / \mathrm{d} z$, with a steeper gradient in the sediment than in the DBL (e.g. Gundersen \& Jørgensen 1990). This is in accordance with simple 1-dimensional, Fickian diffusion theory. The steeper gradient is due to (a) the sediment diffusion coefficient, $D_{\mathrm{S}}$, being lower than the molecular diffusion coefficient, $D$, in the water and (b) the porosity, $\phi$, of the sediment being $<1$. To maintain mass conservation, the diffusive $\mathrm{O}_{2}$ flux, $J$, must be the same just above and below the sediment-water interface. Consequently, the gradients must compensate for the shift in diffusion coefficients and in porosity:

Diffusion in DBL: $J=-D(\mathrm{~d} C / \mathrm{d} z)_{\mathrm{DEL}}$

Diffusion in sediment: $J=-\phi D_{\mathrm{S}}(\mathrm{d} C / \mathrm{d} z)_{\text {sediment }}$

Thus

$$
D(\mathrm{~d} C / \mathrm{d} z)_{\mathrm{DBL}}=\phi D_{\mathrm{S}}(\mathrm{d} C / \mathrm{d} z)_{\text {sediment }}
$$

or

$$
(\mathrm{d} C / \mathrm{d} z)_{\mathrm{DBL}} /(\mathrm{d} C / \mathrm{d} z)_{\text {sediment }}=\phi D_{\mathrm{S}} / D
$$

The DBL must be included in a realistic model of $\mathrm{O}_{2}$ uptake (cf. Hall et al. 1989). This is done by equating the $\mathrm{O}_{2}$ flux through the DBL (Eq. 2) with the $\mathrm{O}_{2}$ flux from the sediment-water interface into the sediment [Eq. (5) for zero-order and Eq. (11) for first-order kinetics]. For zero-order kinetics:

$$
\left(2 C_{0} R D_{\mathrm{S}}\right)^{1 / 2}=D\left(C_{w}-C_{0}\right) / z_{\delta}
$$


This equation is then solved for $C_{0}$ (Hall et al. 1989):

$C_{0}=C_{\mathrm{w}}+\left(z_{\delta}^{2} / D^{2}\right) R D_{\mathrm{S}}\left(1-\left(2 D^{2} C_{\mathrm{w}} / R D_{\mathrm{S}} z_{\delta}^{2}+1\right)^{1 / 2}\right)$

When $C_{0}$ is known from Eq. (17) for a given $\mathrm{O}_{2}$ concentration, $C_{w}$, in the overlying, mixed seawater, the whole $\mathrm{O}_{2}$ microgradient can be modeled by Eq. (2) in the DBL and by Eq. (4) within the sediment.

Similar calculations for first-order kinetics yield:

$$
C_{o}\left(D_{\mathrm{S}} K\right)^{1 / 2}=D\left(C_{\mathrm{w}}-C_{0}\right) / z_{\delta}
$$

This equation is similarly solved for $C_{0}$ :

$$
C_{o}=C_{w} /\left(\left(Z_{\delta} / D\right)\left(D_{\mathrm{S}} K\right)^{1 / 2}+1\right)
$$

and can then be used to compute the whole $\mathrm{O}_{2}$ microgradient by Eqs. (2) and (10).

Total oxygen uptake. Rates of total $\mathrm{O}_{2}$ consumption were measured in the same 6 sediment cores after microelectrode measurements. The following technique ensured identical conditions for the 2 sets of determinations.

A rubber stopper penetrated by a $5 \mathrm{~mm}$ interior diameter glass tube, just wide enough for the $\mathrm{O}_{2}$ microelectrode to pass through, was carefully but tightly positioned on each coring tube. The stopper left a $6 \mathrm{~cm}$ high water column without air bubbles over the sediment. Water in the glass tube was replaced by paraffin oil which impeded $\mathrm{O}_{2}$ exchange but allowed penetration of the $\mathrm{O}_{2}$ microelectrode.

The $\mathrm{O}_{2}$ concentration in the stirred water phase of each core was measured at $0.5 \mathrm{~h}$ intervals for $3 \mathrm{~h}$, during which a linear $\mathrm{O}_{2}$ decrease of 10 to $20 \%$ was measured. The same $\mathrm{O}_{2}$ microelectrode was consecutively inserted into each core. For each round of measurements, the electrode was calibrated at the same temperature in seawater bubbled with $\mathrm{N}_{2}$ or air. At the end of incubation, the heights of the water columns were measured and the $\mathrm{O}_{2}$ uptake rates were calculated in $\mu \mathrm{mol} \mathrm{O}_{2} \mathrm{~m}^{-2}$ of sediment surface $\mathrm{h}^{-1}$. The sediment of some cores was subsequently sieved through $0.5 \mathrm{~mm}$ mesh size to collect the burrowing macrofauna. Faunal density was later related to the $\mathrm{O}_{2}$ uptake of the sediment

Control experiments with $\mathrm{O}_{2}$-depleted, sterile seawater in the coring tubes showed that penetration of $\mathrm{O}_{2}$ into the tubes through the Plexiglas walls and stoppers during normal core incubation was $<2 \mu \mathrm{M} \mathrm{h}^{-1}$, which was insignificant $(<5 \%)$ for the $\mathrm{O}_{2}$ uptake experiments. The thin film of paraffin oil coating the microelectrode tip by the present procedure does not affect electrode calibration (Revsbech \& Ward 1983).

Effect of $\mathrm{O}_{2}$ concentration on diffusive flux. The effect on the diffusive oxygen flux of the $\mathrm{O}_{2}$ concen- tration in the overlying water was determined experimentally on 2 occasions. Sediment cores were incubated under standard conditions at $100 \%$ air saturation of $\mathrm{O}_{2}$ for several hours. Incubations were done at in situ temperature and $4 \mathrm{O}_{2}$ microprofiles were measured at random positions. The $\mathrm{O}_{2}$ concentration in the overlying water was then lowered to $75 \%$ of air saturation and subsequently to $50 \%, 25 \%$, and $10 \%$. The $\mathrm{O}_{2}$ microprofiles were measured again at the same 4 positions at each constant $\mathrm{O}_{2}$ level when steady state $\mathrm{O}_{2}$ microgradients had been reached after about $2 \mathrm{~h}$ (cf. Booij 1989). The $\mathrm{O}_{2}$ level was then increased stepwise again to the previous concentrations, and $\mathrm{O}_{2}$ microprofiles were measured after $2 \mathrm{~h}$ equilibration.

Determination of sediment porosity, $D_{5}$, and organic carbon. The porosity, $\phi$, was determined at $2 \mathrm{~mm}$ depth intervals from the weight loss upon drying at $105^{\circ} \mathrm{C}$ of sediment core segments of known weight and volume. Values of the sediment diffusion coefficient, $D_{\mathrm{S}}$, were then determined from the porosity according to:

$$
D_{\mathrm{S}}=D /(1+3(1-\phi))
$$

This relation was found experimentally to account well for methane diffusing in similar fine-grained marine sediments from Danish waters (Iversen \& Jørgensen in press). A relation proposed by Ullman \& Aller $(1982), D_{\mathrm{S}}=D \phi^{2}$, was found to generate $D_{\mathrm{S}}$ values $5 \%$ higher.

The organic carbon content of dried sediment was determined by a C/N analyzer (Carlo Erba 1500) after acidification to remove carbonates. Total organic matter was determined as weight loss of dried sediment upon ignition at $540^{\circ} \mathrm{C}$ for $3 \mathrm{~h}$.

\section{RESULTS}

\section{Diffusive oxygen flux}

The diffusion of $\mathrm{O}_{2}$ across the sediment-water interface was calculated according to Eq. (1) from each measured $\mathrm{O}_{2}$ microgradient as shown in Fig. 1. In the 2 examples, there was a distinct DBL which could be recognized from 2 shifts in the slope of the $\mathrm{O}_{2}$ gradient. The $\mathrm{O}_{2}$ gradients increased by a factor of 1.9 (Curve A) and 1.7 (Curve $B$ ) at the transition from the DBL to the sediment. Given the measured porosity, $\phi=0.87$ (Table 1 ), and calculated values of $D$ and $D_{\mathrm{S}}$ of $1.57 \times 10^{-5}$ and $1.13 \times 10^{-5} \mathrm{~cm}^{2} \mathrm{~s}^{-1}$, the expected factor of increase (Eq. 15) should be $1.6\left[D / D_{\mathrm{S}} \phi=1.57 \times\right.$ $\left.10^{-5} /\left(1.13 \times 10^{-5} \times 0.87\right)\right]$. Many of the $\mathrm{O}_{2}$ gradients, however, did not show a detectable shift in slope across the sediment-water interface.

The $\mathrm{O}_{2}$ gradient in the DBL was $460 \mu \mathrm{M} \mathrm{cm}^{-1}$ or $0.46 \mu \mathrm{mol} \mathrm{cm}{ }^{-4}$ on 14 November (Fig. 1, Curve A). With a molecular $\mathrm{O}_{2}$ diffusion coefficient, $D$, of $1.51 \times$ 


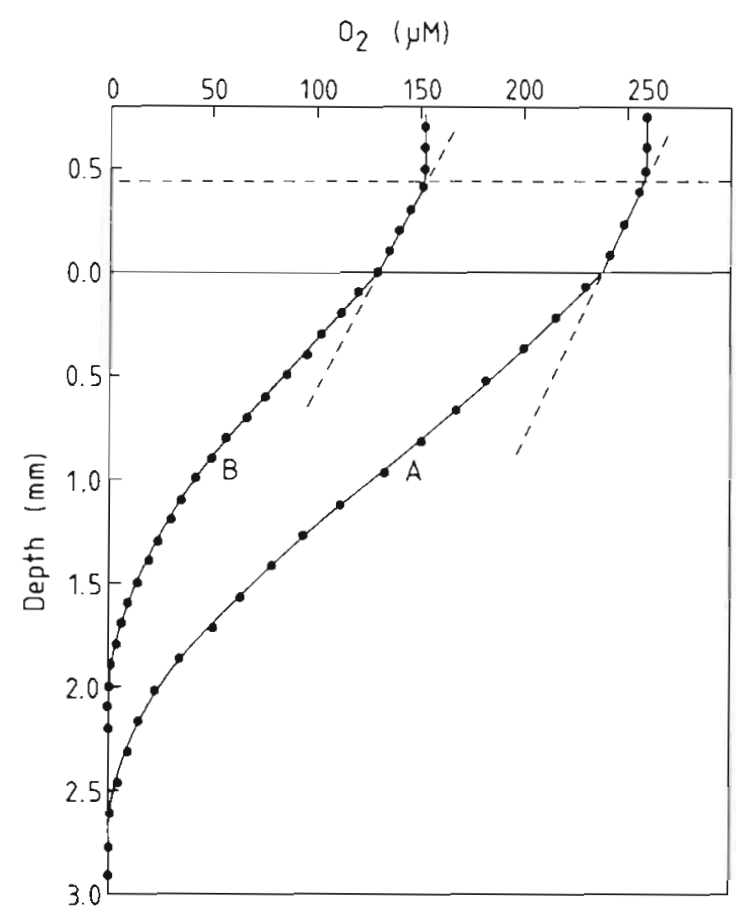

Fig. 1. Oxygen microgradients measured in Aarhus Bay sediment on (A) 14 November 1988 and (B) 5 July 1988. In situ and incubation $\mathrm{O}_{2}$ concentrations in the overlying water were (A) $84 \%$ and (B) $51 \%$ of air saturation. The diffusive boundary layers (DBLs) were $400 \mu \mathrm{m}$ thick. A linear slope was fitted to the $\mathrm{O}_{2}$ gradient measured within the DBL and used to calculate the diffusive $\mathrm{O}_{2}$ uptake rate of the sediment

$10^{-5} \mathrm{~cm}^{2} \mathrm{~s}^{-1}$ at the in situ temperature of $8.5^{\circ} \mathrm{C}$, the calculated $\mathrm{O}_{2}$ flux was $6.95 \times 10^{-6} \mu \mathrm{mol} \mathrm{O}_{2} \mathrm{~cm}^{-2} \mathrm{~s}^{-1}$ or $251 \mu \mathrm{mol} \mathrm{O} \mathrm{m}^{-2} \mathrm{~h}^{-1}$. During summer, the DBL gradient was similar due to the lower $\mathrm{O}_{2}$ concentration, whereas the $\mathrm{O}_{2}$ diffusion coefficient was higher due to the higher temperature. The calculated $\mathrm{O}_{2}$ uptake of the sediment was $282 \mu \mathrm{mol} \mathrm{O} \mathrm{m}^{-2} \mathrm{~h}^{-1}$ (Fig. 1, Curve B).

For each sampling date, $4 \mathrm{O}_{2}$ microgradients were measured in each of 6 cores, and the diffusive fluxes and the mean diffusive $\mathrm{O}_{2}$ uptake were calculated. The relative standard deviation of this mean was $\pm 5 \%$.
The DBL thickness in Fig. 1 was $400 \mu \mathrm{m}$. At the applied depth resolution of $100 \mu \mathrm{m}, 3$ to 5 data points generally fell within the DBL, which was just sufficient for the calculation of a slope. A resolution of $100 \mu \mathrm{m}$ or less is thus required to identify the DBL. During the entire study, we found the mean DBL thickness for these sediments and flow conditions to be $299 \pm 99 \mu \mathrm{m}$ $( \pm$ SE, $n=79)$

\section{Modeling of oxygen consumption: zero-order}

$\mathrm{O}_{2}$ consumption rates within the oxic surface layer of the sediment were calculated from $\mathrm{O}_{2}$ microgradients assuming zero-order kinetics. Fig. $2 \mathrm{~A}$ and $\mathrm{B}$ show 2 examples of $\mathrm{O}_{2}$ gradients measured in spring, just before and after settling of the spring phytoplankton bloom. Before settling, $\mathrm{O}_{2}$ penetrated $5 \mathrm{~mm}$ into the sediment, while after the high input of fresh phytoplankton detritus, the $\mathrm{O}_{2}$ zone was narrowed down to $1.3 \mathrm{~mm}$.

Before the spring bloom, the whole $\mathrm{O}_{2}$ gradient was modeled well by a single parabola (Fig. 2A) from which the curvature, $\mathrm{d}^{2} \mathrm{C} / \mathrm{dz} z^{2}$, was calculated. Sediment porosity decreased with depth from 0.87 in the uppermost 0 to $2 \mathrm{~mm}$ to 0.80 at 30 to $40 \mathrm{~mm}$ depth (Table 1). Only the surface porosity of 0.87 was used here, and the calculated sediment diffusion coefficient was thus, $D_{\mathrm{S}}=D /(1+3(1-0.87))=0.72 D(\mathrm{Eq} .20)$. At the in situ temperature of $4{ }^{\circ} \mathrm{C}$, the calculated $\mathrm{O}_{2}$ consumption rate within the oxic zone was (Eq. 3):

$$
\begin{aligned}
R & =(0.72)\left(1.28 \times 10^{-5}\right)\left(7.9 \times 10^{3}\right) \\
& =7.3 \times 10^{-2} \mu \mathrm{mol} \mathrm{O} \mathrm{cm}^{-3} \mathrm{~h}^{-1}
\end{aligned}
$$

Following the spring bloom, the curvature and thus the $\mathrm{O}_{2}$ consumption rate per sediment volume increased (Fig. 2B). Furthermore, the curvature was strongest at the bottom of the $\mathrm{O}_{2}$ zone, which indicated a more intense $\mathrm{O}_{2}$ consumption rate here. A maximal intensity of $\mathrm{O}_{2}$ consumption near the oxic-anoxic

Table 1. Distribution of density, water content, porosity and organic content in Aarhus Bay sediment. Mean \pm SE of 17 determinations during a year (E. Lomstein data)

\begin{tabular}{|ccccc|}
\hline $\begin{array}{c}\text { Depth } \\
(\mathrm{mm})\end{array}$ & $\begin{array}{c}\text { Density } \\
\left(\mathrm{g} \mathrm{cm}^{-3}\right)\end{array}$ & $\begin{array}{c}\text { Water content } \\
\text { (wt/wt) }\end{array}$ & $\begin{array}{c}\text { Porosity } \\
\text { (vol/vol) }\end{array}$ & $\begin{array}{c}\text { Organic matter } \\
\text { (\% dry wt) }\end{array}$ \\
\hline $0-2$ & $1.18 \pm 0.04$ & $0.74 \pm 0.03$ & $0.87 \pm 0.05$ & $10.1 \pm 0.9$ \\
$2-4$ & $1.22 \pm 0.03$ & $0.70 \pm 0.03$ & $0.86 \pm 0.04$ & $9.6 \pm 0.9$ \\
$4-7$ & $1.24 \pm 0.02$ & $0.69 \pm 0.02$ & $0.85 \pm 0.03$ & $9.3 \pm 0.6$ \\
$7-10$ & $1.25 \pm 0.02$ & $0.68 \pm 0.02$ & $0.85 \pm 0.03$ & $9.3 \pm 0.6$ \\
$10-15$ & $1.26 \pm 0.02$ & $0.66 \pm 0.02$ & $0.83 \pm 0.03$ & $9.0 \pm 0.6$ \\
$15-20$ & $1.28 \pm 0.02$ & $0.64 \pm 0.01$ & $0.82 \pm 0.02$ & $8.9 \pm 0.7$ \\
$20-30$ & $1.30 \pm 0.04$ & $0.63 \pm 0.01$ & $0.82 \pm 0.03$ & $8.4 \pm 0.6$ \\
$30-40$ & $1.32 \pm 0.03$ & $0.61 \pm 0.02$ & $0.80 \pm 0.03$ & $7.7 \pm 1.0$ \\
\hline
\end{tabular}



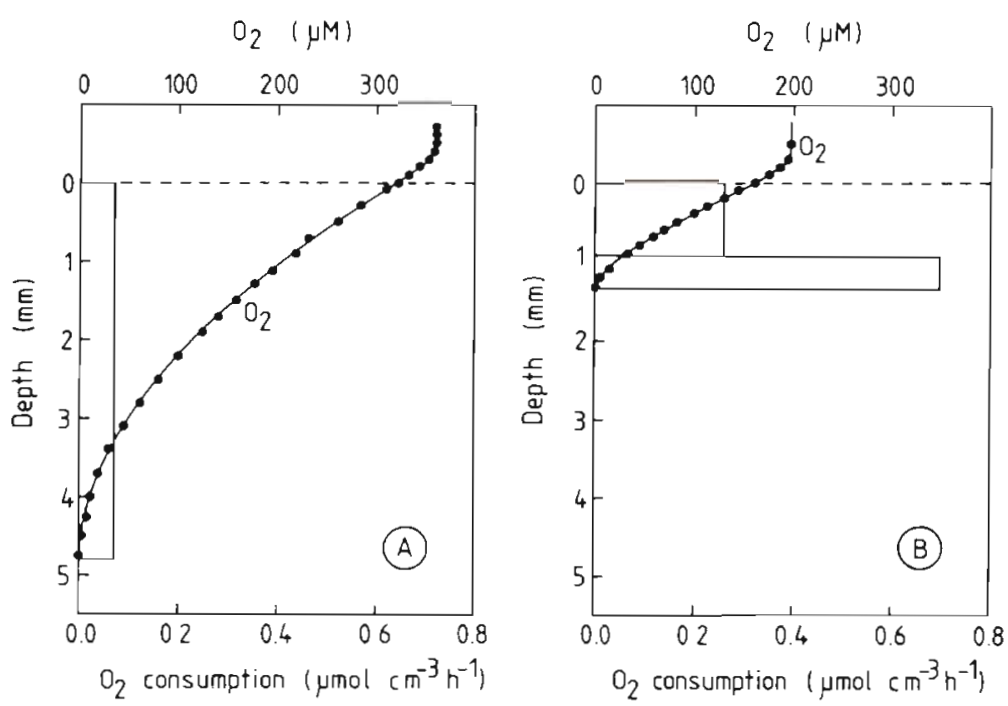

Fig. 2. Oxygen microgradients measured on (A) 18 March and (B) 18 April. Parabolas [1 in (A), 2 in $(B)\}$ were fitted to the data sets and used to calculate the rates of $\mathrm{O}_{2}$ consumption within the oxic sediment layer. After a phytoplankton bloom in late March, the oxic zone was reduced in thickness, and the intensity of $\mathrm{O}_{2}$ consumption increased strongly with maximal rate near the oxic-anoxic interface interface in the sediment was commonly observed and modeled during late spring and summer, but was not seen during the winter.

The total $\mathrm{O}_{2}$ consumption per unit sediment area was calculated from the modeled $\mathrm{O}_{2}$ consumption rates. It was found that this areal $\mathrm{O}_{2}$ consumption calculation was not very sensitive to whether the $\mathrm{O}_{2}$ microgradient was modeled by a single parabola or the oxic zone was divided into several depth intervals of different $\mathrm{O}_{2}$ consumption rates.

\section{Modeling of oxygen consumption with a DBL}

It was generally possible to model the whole $\mathrm{O}_{2}$ microgradient in both DBL and sediment by a single zero-order model given in Eqs. (17), (2) \& (4). In the example shown in Fig. 3, the DBL was $400 \mu \mathrm{m}$ thick, the diffusion coefficient in the water was $1.57 \times$ $10^{-5} \mathrm{~cm}^{2} \mathrm{~s}^{-1}$, and $\mathrm{O}_{2}$ in the overlying water, $308 \mu \mathrm{M}$, was close to air saturation at the in situ temperature. A constant $\mathrm{O}_{2}$ consumption, $R$, of $0.108 \mu \mathrm{mol} \mathrm{O} \mathrm{Cm}^{-3} \mathrm{~h}^{-1}$ yielded a perfect fit throughout the oxic zone and also generated the observed gradient in the DBL. The depth of $\mathrm{O}_{2}$ penetration, $z_{\max }$, was $4.6 \mathrm{~mm}$ and the total $\mathrm{O}_{2}$ consumption rate per unit area was thus, $R z_{\max }=$ $(0.108)\left(0.46 \times 10^{4}\right)=490 \mu \mathrm{mol} \mathrm{O} \mathrm{m}^{-2} \mathrm{~h}^{-1}$. The $\mathrm{O}_{2}$ gradient, $\mathrm{d} C / \mathrm{d} z$, across the $400 \mu \mathrm{m}$ thick $\mathrm{DBL}$ was $(308-273) / 0.04=875 \mu \mathrm{M} \mathrm{cm}^{-1}$, and the diffusion flux was thus, $D \mathrm{dC} / \mathrm{d} z=\left(1.57 \times 10^{-5}\right)(875)=0.0138 \mathrm{nmol}$ $\mathrm{O}_{2} \mathrm{~cm}^{-2} \mathrm{~s}^{-1}$ or $490 \mu \mathrm{mol} \mathrm{O} \mathrm{m}^{-2} \mathrm{~h}^{-1}$, i.e. identical to the $\mathrm{O}_{2}$ consumption within the sediment.

The effects of increasing or decreasing the modeled rate of $\mathrm{O}_{2}$ consumption in the sediment by a factor of 2 are shown in Fig. 3. The model is seen to be quite sensitive to the $\mathrm{O}_{2}$ consumption rate. The dashed line in Fig. 3 shows the results of a calculation based on a first-order kinetic model. It is evident that the calculated exponential $\mathrm{O}_{2}$ distribution does not describe the data well. Based on the shape of $\mathrm{O}_{2}$ microprofiles it was therefore concluded that $\mathrm{O}_{2}$ consumption rates did not vary with depth in proportion to the $\mathrm{O}_{2}$ concentration.

\section{Seasonal variation in Aarhus Bay}

Aarhus Bay is hydrographically a part of the Baltic Sea-North Sea transition system where brackish water and oceanic water meet with resulting seasonal

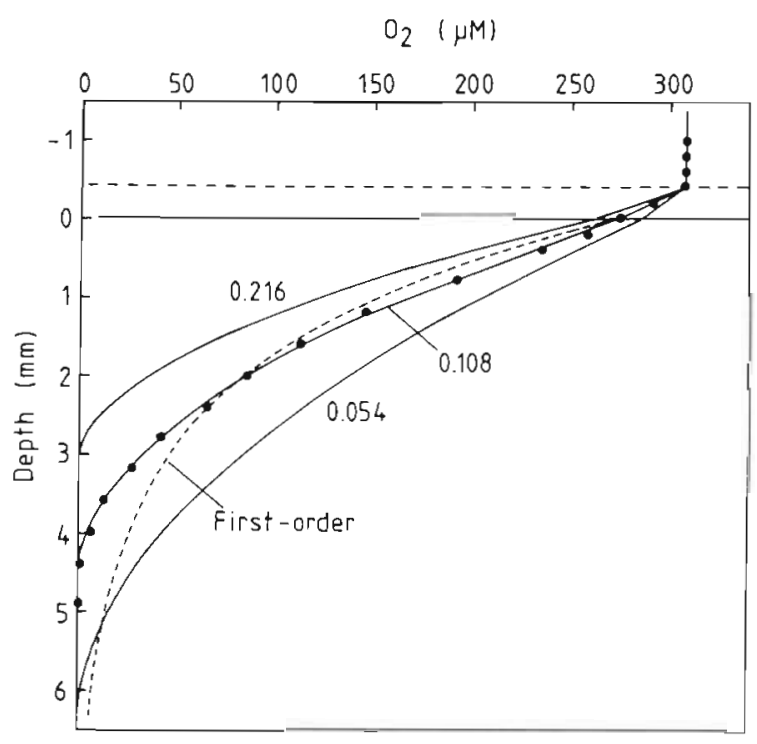

Fig. 3. Modeling of $\mathrm{O}_{2}$ in both diffuse boundary layer and sediment from an $\mathrm{O}_{2}$ microgradient $(\bullet)$ measured on 7 December. Dashed line: $\mathrm{O}_{2}$ distribution calculated by first-order model; solid lines: $\mathrm{O}_{2}$ distributions calculated by zero-order model with 3 different rates of $\mathrm{O}_{2}$ consumption within the sediment. Numbers indicate rates in $\mu \mathrm{mol} \mathrm{O} \mathrm{Cm}^{-3} \mathrm{~h}^{-1}$ 
stratification (Andersson \& Rydberg 1988). Seasonal variations in temperature, salinity, and $\mathrm{O}_{2}$ concentration in the water column overlying the sampling station are shown in Fig. 4. The whole water column was well mixed and oxygenated during winter. During spring and summer, stratification developed between the more brackish surface water from the Baltic Sea and more saline bottom water from the North Sea. This stratification was stabilized by a temperature gradient with a $\Delta t$ of up to $12^{\circ} \mathrm{C}$ in early summer when heating of the surface water was fastest. The seawater just over the sediment thus had temperatures varying from 4 to $15^{\circ} \mathrm{C}$ over the year and salinities varying from 23 to $32 \%$ (Fig. 4). The pycnocline was mostly situated at

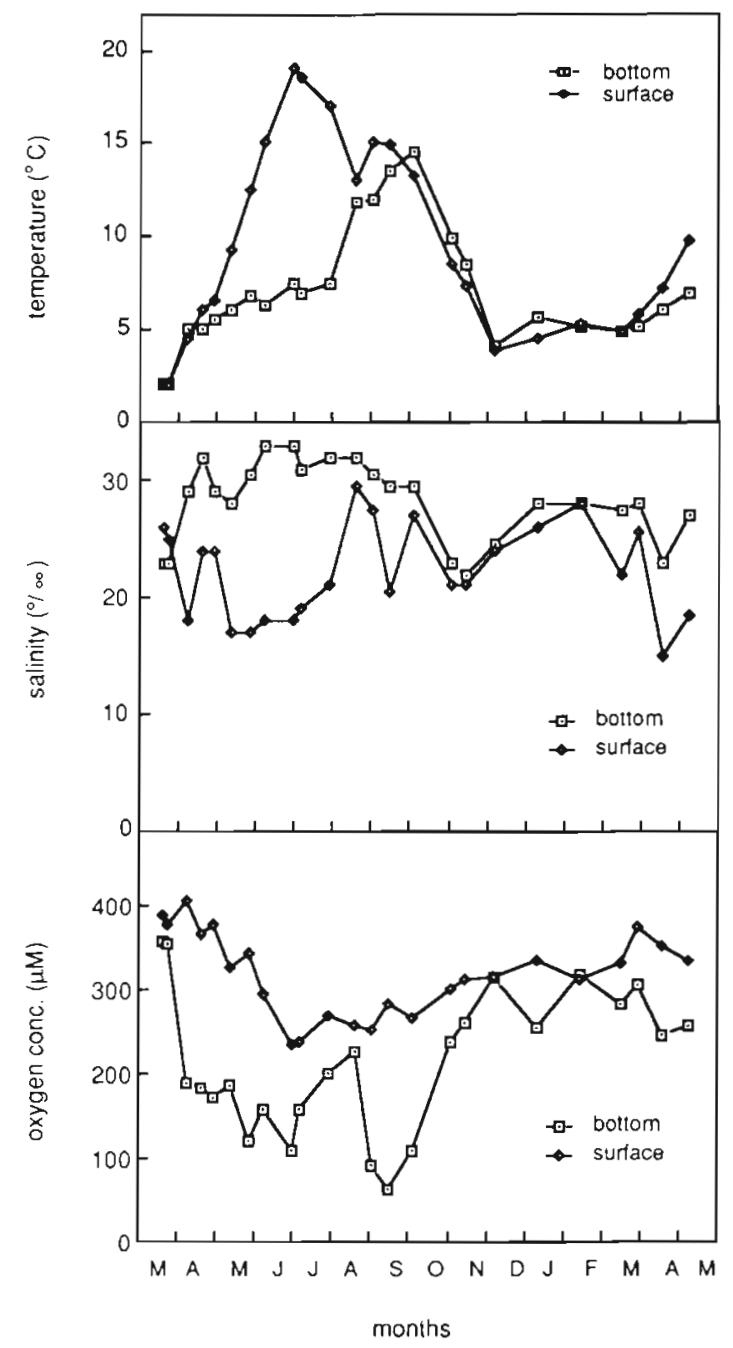

Fig. 4. Seasonal variation in temperature, salinity, and oxygen concentration of Aarhus Bay water measured $1 \mathrm{~m}$ below the water surface and $1 \mathrm{~m}$ above the bottom. Temperature and salinity stratification, which developed during spring and summer and lasted into the fall, caused partial oxygen depletion in the bottom water
10 to $12 \mathrm{~m}$ water depth but varied considerably due to wind-induced seiching. Light penetration was limited by high phytoplankton biomass in the surface water and the euphotic zone did not extend down below the pycnocline during most of spring and summer.

Due to the stable stratification and to $\mathrm{O}_{2}$ respiration in the bottom water and sediment, $\mathrm{O}_{2}$ was strongly depleted below air saturation during spring, summer and fall (Fig. 4). The first decrease in $\mathrm{O}_{2}$ concentration occurred just after the spring phytoplankton bloom at the end of March. Oxygen increased again during windy periods in July-August as the water masses in the bay were exchanged. A new, stable stratification in September led to extensive $\mathrm{O}_{2}$ depletion in the 13 to $15{ }^{\circ} \mathrm{C}$ bottom water with an $\mathrm{O}_{2}$ minimum of $23 \%$ of air saturation.

\section{The oxic sediment zone}

The depth of $\mathrm{O}_{2}$ penetration into the sediment varied 4 -fold over the seasons with a maximum penetration of $5.1 \mathrm{~mm}$ during winter and a minimum of $1.2 \mathrm{~mm}$ during spring and early fall (Fig, 5). As the spring phytoplankton bloom settled on the sediment surface at the end of March 1988, the thickness of the oxic zone decreased 2- to 3 -fold within 1 to $2 \mathrm{wk}$. At this time there was a 1 to $2 \mathrm{~mm}$ thick, brown and flocculent layer of Skeletonema costatum and other diatoms on the sediment surface. Photosynthesis measurements by the light-dark shift technique (Revsbech \& Jørgensen 1983) showed a slight photosynthetic response in $\mathrm{O}_{2}$ concentration at the sediment surface in early April, but photosynthesis was not detectable at any other time of the year. The thickness of the oxic zone remained at 1.3 to $2.5 \mathrm{~mm}$ throughout the summer but reached a new minimum in September. During late fall and winter, oxygen slowly penetrated deeper into the sediment until the cycle was repeated next spring. There was, however, no distinct phytoplankton bloom during the spring of 1989.

The $\mathrm{O}_{2}$ penetration into the sediment varied seasonally in close accordance with the $\mathrm{O}_{2}$ concentration in the overlying seawater (Fig. 5). A decrease in the $\mathrm{O}_{2}$ concentration of the water was thus immediately reflected in a narrower $\mathrm{O}_{2}$ zone in the sediment. This shows the importance of measuring $\mathrm{O}_{2}$ microgradients under in situ $\mathrm{O}_{2}$ concentration and temperature conditions.

\section{Oxygen uptake by 3 methods}

Fig. 6 shows the $\mathrm{O}_{2}$ uptake rates of Aarhus Bay sediment throughout a year as measured by 3 differ- 


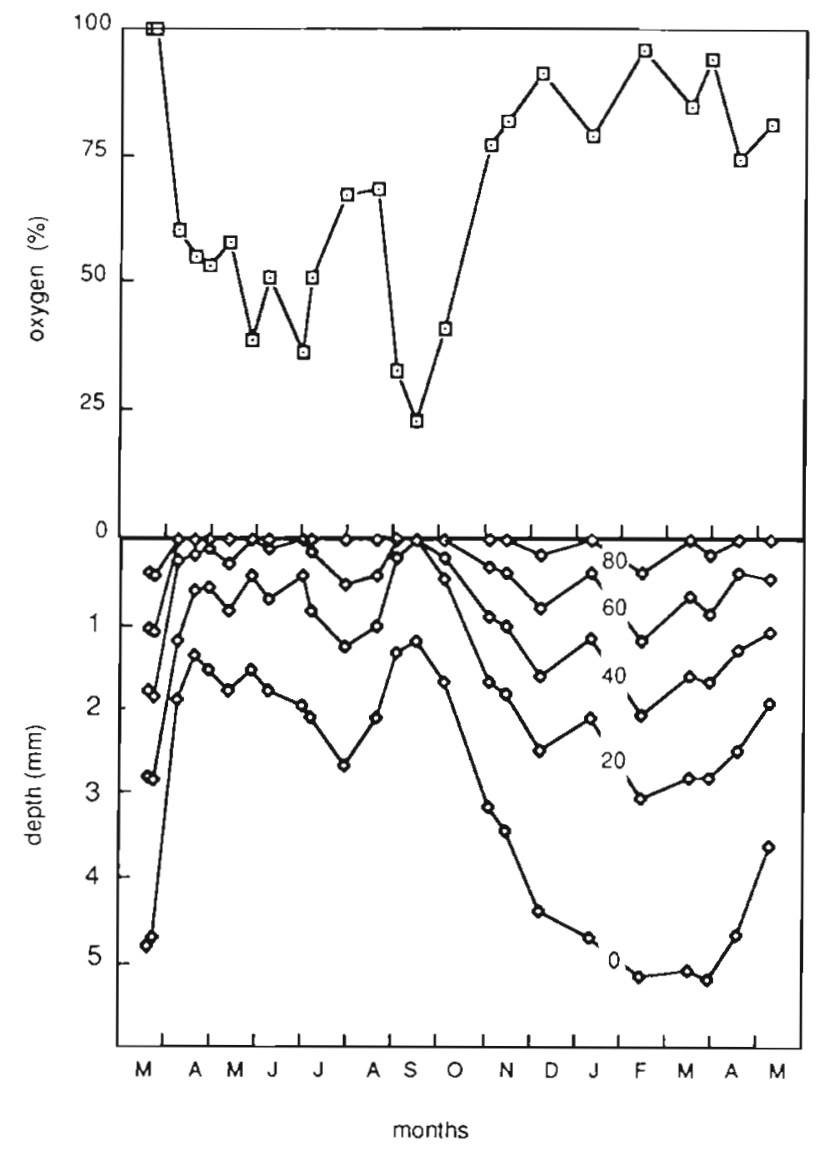

Fig. 5. Upper frame: Seasonal $\mathrm{O}_{2}$ concentrations in the seawater $1 \mathrm{~m}$ above the sediment calculated as $\%$ of air saturation. Lower frame: $\mathrm{O}_{2}$ penetration into the sediment shown as isopleths of $\mathrm{O}_{2}$ concentration in \% of air saturation (numbers on curves)

ent methods: (a) total $\mathrm{O}_{2}$ uptake, (b) diffusive $\mathrm{O}_{2}$ flux through the DBL and (c) modeling of $\mathrm{O}_{2}$ microgradients. The total $\mathrm{O}_{2}$ uptake was highest during summer and lowest during late winter while the calculated $\mathrm{O}_{2}$ flux and the modeled $\mathrm{O}_{2}$ uptake were rather constant over the year.

The $\mathrm{O}_{2}$ uptake rates measured by the 3 methods were compared throughout the year. The annual mean $\mathrm{O}_{2}$ diffusion through the DBL was $99 \pm 3 \%$ of the modeled $\mathrm{O}_{2}$ uptake. There was thus a close correspondence between the 2 approaches, which are based on different parts of the $\mathrm{O}_{2}$ microgradients. The total $\mathrm{O}_{2}$ uptake of the sediment was significantly higher, an average of $145 \%$ of the flux and model rates over the whole year. The difference varied highly between sediment cores depending on the occurrence of macrofauna in each core. In the absence of macrofauna, total $\mathrm{O}_{2}$ uptake was similar to diffusive $\mathrm{O}_{2}$ uptake. When the numbers of macrofauna per core $\left(20 \mathrm{~cm}^{2}\right)$ increased to $1-3,4-6$, and $>7$ individuals, total $\mathrm{O}_{2}$



Fig. 6. Seasonal variations in $\mathrm{O}_{2}$ uptake rates of Aarhus Bay sediment measured under in situ conditions of salinity, temperature, and $\mathrm{pO}_{2}$ by 3 methods. Top: Total $\mathrm{O}_{2}$ uptake. Middle: Diffusive $\mathrm{O}_{2}$ uptake calculated from $\mathrm{O}_{2}$ microgradients in the diffuse bottom layer. Bottom: $\mathrm{O}_{2}$ uptake calculated by modeling $\mathrm{O}_{2}$ microgradients within the sediment. Vertical bars indicate standard deviations

uptake exceeded diffusive $\mathrm{O}_{2}$ uptake by $100-150 \%$, $150-200 \%$, and $>200 \%$, respectively. Thus, the total $\mathrm{O}_{2}$ uptake in excess of the diffusive uptake was strongly related to the ventilation and respiration by macrofauna.

\section{Oxygen uptake regulation by oxygen concentration}

Experimental variation of $\mathrm{O}_{2}$ concentration in the seawater overlying the sediment cores showed how diffusive $\mathrm{O}_{2}$ uptake and depth of the oxic zone depended on the $\mathrm{O}_{2}$ saturation level. The diffusive $\mathrm{O}_{2}$ uptake of the sediment decreased 7 -fold when $\mathrm{O}_{2}$ 
concentration in the seawater was stepwise reduced 10 -fold, from 100 to $10 \%$ of air saturation (Fig. 7A, solid circles). When $\mathrm{O}_{2}$ concentration was subsequently increased again to $100 \%$, the original $\mathrm{O}_{2}$ uptake was again nearly reached (open circles). The depth of $\mathrm{O}_{2}$ penetration decreased only 2.5 -fold when $\mathrm{O}_{2}$ concentration was reduced 10-fold (Fig. $7 \mathrm{~B}$ ). Also the $\mathrm{O}_{2}$ penetration was reversible, as seen when the original $100 \% \quad \mathrm{O}_{2}$ level was again reached. Regulation of the oxic zone under decreasing and increasing $\mathrm{O}_{2}$ levels was thus reproducible under these experimental conditions. This experiment was repeated 3 mo later with similar results and conclusions.

In order to evaluate by which mechanisms $\mathrm{O}_{2}$ concentration regulated $\mathrm{O}_{2}$ uptake and depth of the oxic zone, data were modeled assuming zero-order kinetics. All parameters used in the model were independently determined or calculated according to Eqs. (17), (2) \& (4). The mean measured DBL thickness was $300 \mu \mathrm{m}$.

Fig. $7 \mathrm{~A}$ shows calculated $\mathrm{O}_{2}$ fluxes (solid lines) at 3 different $\mathrm{O}_{2}$ consumption rates and at varying $\mathrm{O}_{2}$ concentrations in the seawater. A constant $\mathrm{O}_{2}$ con- sumption rate of $0.082 \mu \mathrm{mol} \mathrm{O}_{2} \mathrm{~cm}^{-3} \mathrm{~h}^{-1}$ throughout the oxic zone gave the closest fit to the measured fluxes. Results from 2-fold higher or 2-fold lower activities (Fig. 7A) shows that the model calculations are very sensitive to rates of $\mathrm{O}_{2}$ consumption. The zeroorder model, however, did not produce as strong a variation in $\mathrm{O}_{2}$ flux with changing $\mathrm{O}_{2}$ concentration as was observed. Calculations using a first-order model (Fig 7A, dashed line), in which the flux is proportional to $C_{0}$, exaggerated the variation relative to the observations.

Fig. 7B shows similarly the observed and the modeled depths of $\mathrm{O}_{2}$ penetration into the sediment. Modeled data were calculated from the same parameter values as in Fig. 7A. Both zero-order and first-order models exaggerated the variation in thickness of the oxic zone with varying $C_{0}$, yet zero-order kinetics yielded the better fit.

Similar calculations were made with the best-fitting $\mathrm{O}_{2}$ consumption rate of $0.082 \mu \mathrm{mol} \mathrm{O}_{2} \mathrm{~cm}^{-3} \mathrm{~h}^{-1}$ but with DBL thicknesses of 0,300 , and $600 \mu \mathrm{m}$ (Fig. $7 \mathrm{C}$ $\&$ D). For the present conditions of water flow, $\mathrm{O}_{2}$ consumption rates, etc., there was only little effect of DBL thickness on $\mathrm{O}_{2}$ flux or $\mathrm{O}_{2}$ penetration.
Fig. 7. Oxygen uptake and penetration depth during experimental variation of $\mathrm{O}_{2}$ concentration in seawater overlying sediment from Aarhus Bay, 19 November 1988. The $\mathrm{O}_{2}$ concentration was changed stepwise from 100 to $10 \%$ of air saturation $(\bullet)$ and stepwise back again (O) over a period of 16 h. (A) \& (C) Rates of $\mathrm{O}_{2}$ uptake calculated from diffusive flux through the DBL. (B) \& (D) Depths of $\mathrm{O}_{2}$ penetration. Solid lines: Modeling with zero-order kinetics; dashed lines: modeling with first-order kinetics. Model calculations were made for (A) and (B) using different $\mathrm{O}_{2}$ consumption rates (numbers on curves indicate $\mathrm{O}_{2}$ consumption rates in $\mu \mathrm{mol} \mathrm{cm}^{-3} \mathrm{~h}^{-1}$ ) and for (C) and (D) using different DBL thicknesses (numbers on curves indicate DBL thicknesses in $\mathrm{mm}$ )
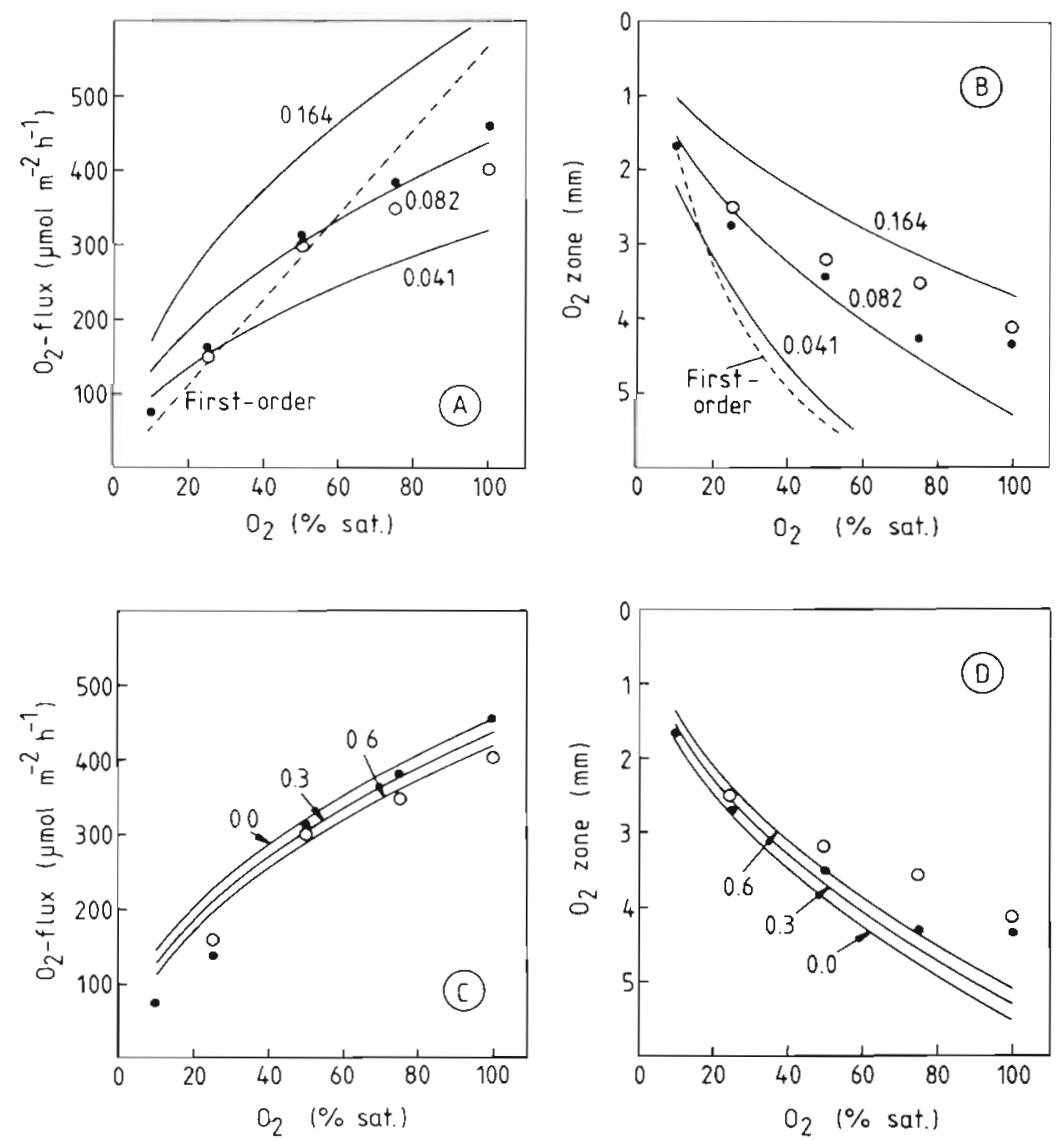


\section{Comparison with other sediment types}

Sediment $\mathrm{O}_{2}$ uptake and $\mathrm{O}_{2}$ microgradients were studied in deeper and more open waters at several positions in Kattegat. The characteristics of these sediments are given in Table 2. At the times of sampling, the overlying seawater was partly depleted in $\mathrm{O}_{2}$ (68 to $95 \%$ saturation) with a low of $27 \%$. The $\mathrm{O}_{2}$ uptake was generally lower than in Aarhus Bay while the oxic zone was thicker, up to $9.1 \mathrm{~mm}$. The total $\mathrm{O}_{2}$ uptake rates were 1.5 - to 2.3-fold higher than the diffusive rates. This difference was not correlated to the $\mathrm{O}_{2}$ concentration or the rate of $\mathrm{O}_{2}$ uptake but was expectedly dependent on the activity of the benthic fauna and other factors such as sediment topography.

\section{DISCUSSION}

\section{Three experimental oxygen uptake methods}

Three different approaches were concurrently used in laboratory-incubated cores to measure the $\mathrm{O}_{2}$ uptake of Aarhus Bay sediment. Two of the methods used the steady state microdistribution of $\mathrm{O}_{2}$ to calculate (a) the diffusion flux through the diffusive boundary layer (DBL) from Fick's first law or (b) the depth-integrated $\mathrm{O}_{2}$ consumption in the oxic sediment layer from Fick's second law assuming zero-order kinetics. It should be noted that, although these 2 methods apply the same oxygen microgradients for the calculations, the former uses data only from above the sediment-water interface while the latter uses data only from within the sediment. The third method, (c), measures the total $\mathrm{O}_{2}$ uptake from the seawater into the sediment.

\section{Diffusive oxygen flux}

A DBL with a mean thickness of about $300 \mu \mathrm{m}$ was consistently found over the sediment surface in the incubated cores. The DBL thickness measured in situ throughout the year by a microprofiling lander instrument at the sampling station in Aarhus Bay was 250 to $500 \mu \mathrm{m}$ (Gundersen \& Jørgensen 1991). The experimental flow conditions were therefore considered an acceptable approximation of the natural flow conditions although the flow pattern was different. Thus, the occurrence of bursts, as predicted by turbulent flow theory (Boudreau 1988), was not observed during prolonged $\mathrm{O}_{2}$ measurements in the DBL. The simulation of a natural DBL thickness is important for the $\mathrm{O}_{2}$ flux into the sediment, especially at high $\mathrm{O}_{2}$ uptake rates (Jørgensen \& Des Marais 1990).

It was recently observed in our laboratory that the use of microelectrodes for DBL studies has a measurable effect on the hydrodynamics of the DBL and thus on the chemical microgradients (R. N. Glud unpubl.). Apparently, even the thin electrode tip of 5 to $10 \mu \mathrm{m}$ diameter causes an acceleration of water flow. This results in a thinner DBL and a steeper $\mathrm{O}_{2}$ gradient, which would result in an overestimation of the diffusive flux. The effect depends on flow velocity and other factors and has presently not been quantified. Judging from the close agreement between DBL flux and modeled $\mathrm{O}_{2}$ consumption within the sediment, however, this experimental artifact did not appear to strongly affect calculated fluxes in the present study.

Calculation of the diffusive $\mathrm{O}_{2}$ flux through the DBL requires a high resolution of the $\mathrm{O}_{2}$ microgradient data. With a DBL thickness of 300 to $400 \mu \mathrm{m}$, measurements should be taken at $100 \mu \mathrm{m}$ depth intervals or less. Furthermore, as the DBL has an inherent shortterm instability, especially at low flow rates (Gundersen \& Jørgensen 1991), the accuracy of the gradient determination can be improved by averaging for each depth in the DBL over time. Flux calculations in the DBL have, however, the advantage of being independent of porosity and turtuosity within the sediment. Flux calculations from pore water microgradients just

Table 2. Characteristics of sediment stations studied in southern Kattegat

\begin{tabular}{|c|c|c|c|c|c|}
\hline \multirow[t]{2}{*}{ Characteristics } & \multicolumn{3}{|c|}{ October 1988} & \multicolumn{2}{|c|}{ April 1989} \\
\hline & Stn 1402 & Stn 409 & Stn 1243 & $\operatorname{Stn} 1402$ & $\operatorname{Stn} 1505$ \\
\hline Water depth (m) & 29 & 13 & 33 & 29 & 25 \\
\hline Sediment type & Muddy sand & Fine sand & Sandy mud & Muddy sand & Muddy sand \\
\hline Organic matter (\% dry wt) & $2-6$ & $<1$ & $3-5$ & $2-6$ & $3-5$ \\
\hline Temperature $\left({ }^{\circ} \mathrm{C}\right)$ & 12.7 & 11.2 & 5.5 & 5.3 & 5.5 \\
\hline Salinity $(\%)$ & 31.4 & 24.8 & 32 & 27 & 30 \\
\hline Water $\mathrm{O}_{2}$ concentration $(\mu \mathrm{M})$ & 75 & 280 & 256 & 231 & 219 \\
\hline Water $\mathrm{O}_{2}$ saturation $(\%)$ & 27 & 95 & 80 & 70 & 68 \\
\hline Total $\mathrm{O}_{2}$ uptake $\left(\mu \mathrm{rrol} \mathrm{m}^{-2} \mathrm{~h}^{-1}\right)$ & $436 \pm 56$ & $539 \pm 53$ & $366 \pm 75$ & $320 \pm 20$ & $475 \pm 76$ \\
\hline Diff. $\mathrm{O}_{2}$ flux $\left(\mu \mathrm{mol} \mathrm{m} \mathrm{m}^{-2} \mathrm{~h}^{-1}\right)$ & $188 \pm 10$ & $350 \pm 23$ & $160 \pm 10$ & $219 \pm 13$ & $247 \pm 15$ \\
\hline Total vs diff. $\mathrm{O}_{2}$ uptake & $2.3 \times$ & $1.5 \times$ & $2.3 \times$ & $1.5 \times$ & $1.9 \times$ \\
\hline Depth of $\mathrm{O}_{2}$ zone $(\mathrm{mm})$ & $1.9 \pm 0.07$ & $3.4 \pm 0.16$ & $9.1 \pm 0.35$ & $5.4 \pm 0.13$ & $6.0 \pm 0.28$ \\
\hline
\end{tabular}


below the sediment-water interface indicated that these properties must be known with high resolution (Reimers \& Smith 1986). Although an experimental approach to determine both porosity and sediment molecular diffusion coefficient for $\mathrm{O}_{2}$ with microelectrodes has been developed by Revsbech (1989a), flux determinations in the DBL depend on fewer variables and are thus simpler. In the present study we found a shift of the $\mathrm{O}_{2}$ gradients across the sedimentwater interface of around 1.6-fold (Fig. 1), corresponding to the relation: $\phi D_{\mathrm{S}}=0.63 \mathrm{D}$. This is close to the relation, $\phi D_{\mathrm{S}}=0.64 \mathrm{D}$, found experimentally by $\mathrm{O}_{2}$ microelectrode methods under stagnant conditions in a fine-grained riverine sediment (Revsbech 1989a).

\section{Modeling of oxygen consumption}

Microgradients of $\mathrm{O}_{2}$ in Aarhus Bay sediment were mostly found to follow parabolic depth distributions which could be closely modeled assuming zero-order kinetics of $\mathrm{O}_{2}$ consumption. Parabolic depth distributions of $\mathrm{O}_{2}$, and thus apparent zero-order kinetics, have been most common in coastal sediments that we and several others have studied (cf. Booij 1989. Hofman et al. 1991). A similarly close fit to the data could not be obtained by exponential depth distributions corresponding to first-order kinetics (Fig. 3). First-order kinetics would imply that microorganisms living in the oxic zone are $\mathrm{O}_{2}$-limited even at near atmospheric $\mathrm{O}_{2}$ concentrations. This is not in accord with the $\mathrm{O}_{2}$ uptake kinetics observed in aerobic microorganisms, which may become $\mathrm{O}_{2}$-limited only at $\mu \mathrm{M}$ levels (e.g. Hao et al. 1983).

A constant $\mathrm{O}_{2}$ consumption rate throughout the oxic zone is, however, an over-simplification due to expected microzonations of respiring organisms within this zone and of the availability of substrates. During the warm season, enhanced $\mathrm{O}_{2}$ consumption was consistently found at the oxic-anoxic interface (Fig. 2B). This was presumably due to a high flux of reduced products, such as $\mathrm{NH}_{4}{ }^{+}, \mathrm{Fe}^{2+}$, or $\mathrm{H}_{2} \mathrm{~S}$, diffusing up to the oxic zone. The enhanced $\mathrm{O}_{2}$ consumption was first observed in mid April 1988, just after a rapid settling of the spring phytoplankton bloom (Fig. 5). During the following $2 \mathrm{wk}$, a thin sediment layer at 2 to $4 \mathrm{~mm}$ depth exhibited very high sulfate reduction activity, and a transient formation of a black band of iron sulfide at that depth indicated that rapid formation of $\mathrm{H}_{2} \mathrm{~S}$ took place (L. Moeslund, B. Thamdrup, \& B. B. Jergensen unpubl.). The enhanced $\mathrm{O}_{2}$ consumption at the oxic-anoxic interface was thus expectedly due to reoxidation of $\mathrm{H}_{2} \mathrm{~S}$. A similar enhancement, corresponding to $60 \%$ of the $\mathrm{O}_{2}$ consumption, due mostly to diffusing methane was found in a temperate lake sediment (Sweerts 1990).
More detailed analyses of $\mathrm{O}_{2}$ microgradients have demonstrated that the uppermost part of the oxic zone, where freshly settling detritus or photosynthesis occurs, may also show elevated $\mathrm{O}_{2}$ consumption rates (Revsbech et al. 1986, Gundersen \& Jørgensen 1991). The precision of such calculations is, however, dependent on the determination of other model parameters such as the sediment diffusion coefficient, $D_{S}$, and porosity, $\phi$. These were assumed constant in the model calculations although they do change with depth (Table 1). In particular at the sediment-water interface there is a gradual transition from water to sediment when observed at $100 \mu \mathrm{m}$ resolution, and the assumption of constant $D_{\mathrm{S}}$ and $\phi$ leads to an underestimation of the $\mathrm{O}_{2}$ consumption rate just below the sedimentwater interface.

This problem may be enhanced by a flow-induced dispersion effect in the top few $\mathrm{mm}$ of the sediment. Based on a hydrodynamic model for the watersediment transition, Svensson \& Rahm (1991) concluded that pore water in the uppermost sediment layer is influenced by shear from the viscous sublayer and that this results in a higher effective exchange several $\mathrm{mm}$ into the sediment. Such an effect is observed mostly in sand (Revsbech et al. 1980a, Booij 1989), where flow of the overlying water tends also to create pressure gradients and thus permeation of the pore water (Hüttel 1988). The apparent diffusion coefficient of $\mathrm{O}_{2}$ has also, however, been found to exceed the calculated molecular diffusion coefficient by 2 -fold in the thin, oxic zone of fine-grained sediments (Lindeboom et al. 1985, Booij 1989, Hofman et al. 1991). Such an enhanced diffusion coefficient in the top few $\mathrm{mm}$ would explain why the $\mathrm{O}_{2}$ gradient frequently did not show a break in slope across the sediment-water interface. Since the modeled $\mathrm{O}_{2}$ consumption accounted for $100 / 1.45=69 \%$ of the total $\mathrm{O}_{2}$ uptake, and since the benthic fauna and other factors must account for much of the remaining $31 \%$, the modeled $\mathrm{O}_{2}$ consumption (and DBL flux) cannot be significantly underestimated. It is therefore concluded that the diffusion of $\mathrm{O}_{2}$ within the oxic zone of this sediment is well described as molecular diffusion.

Although a zero-order model yielded the best fit to measured $\mathrm{O}_{2}$ microgradients, it reproduced only moderately well the diffusive $\mathrm{O}_{2}$ uptake and $\mathrm{O}_{2}$ penetration depth during experimental shifts in $\mathrm{O}_{2}$ saturation levels (Fig. 7). The experiment in Fig. 7 is thus a useful test of the validity of the model assumptions and demonstrates that a correct understanding of the regulation of $\mathrm{O}_{2}$ uptake may require independent knowledge of its microdistribution. Apart from the diffusion coefficient of $\mathrm{O}_{2}$ and the assumption of zero-order kinetics, however, all parameters entering the model were experimentally determined in this study. 


\section{Comparison of the 3 methods}

Oxygen uptake per unit sediment area calculated from diffusion through the DBL and from modeling of $\mathrm{O}_{2}$ microgradients agreed closely. Due to surface microtopography of the sediment, however, the actual, 3-dimensional diffusive flux may be underestimated when calculations are made only from vertical $\mathrm{O}_{2}$ microgradients (Jørgensen \& Des Marais 1990, Jørgensen \& Gundersen 1991). As the sediment surface of the Aarhus Bay station was relatively smooth, microtopography did not appear to be of major importance for the present flux calculations. A practical method for quantification of the relevant sediment topography is, however, required to determine this effect routinely.

The total $\mathrm{O}_{2}$ uptake exceeded the diffusive rates by an average of $45 \%$ (Fig. 6). The difference was clearly related to the density of large burrowing animals such as bivalves (mostly Abra alba, Macoma calcarea, or Nucula tenuis of 13 to $30 \mathrm{~mm}$ length) and polychaetes (mostly Nephtys sp. or Nereis sp.) in each sediment core. The difference was largest, up to 2.6-fold, during summer when the animals were most active, but dropped during periods of $\mathrm{O}_{2}$ depletion in the bottom water, possibly due to inactivation of the animals (Figs. $5 \& 6$ ). The relation between total and diffusive $\mathrm{O}_{2}$ uptake in the surficial oxic zone was also studied in sediments in Kattegat where the difference was 1.5- to 2.3-fold.

Similar published comparisons from other sedimentary environments have reached widely differing conclusions. Reimers \& Smith (1986) found the diffusive $\mathrm{O}_{2}$ uptake to be close to the total uptake in pelagic sediments of the North Pacific. Andersen \& Helder (1987) found the total uptake to exceed the diffusive uptake by 1.4 - to 3.2-fold in intertidal sediments. Mackin \& Swider (1989) found the same ratio to be 2 - to 5 -fold in Flax Pond, New York, USA, sediment but to be 1:1 in Long Island Sound, New York, sediment. They attributed the former difference to epifaunal respiration and concluded that infaunal irrigation was not important for the total $\mathrm{O}_{2}$ uptake. In order to understand the regulation between the different mechanisms and components of the $\mathrm{O}_{2}$ budget, future studies are needed in which total and diffusive $\mathrm{O}_{2}$ uptake measurements are accompanied by analyses of the ventilation and respiration of the benthic fauna.

Total $\mathrm{O}_{2}$ uptake was calculated in most of the cited studies from the apparently linear decrease of $\mathrm{O}_{2}$ concentration in incubated cores over time. It was found by Hall et al. (1989) in benthic flux chamber studies that the apparently linear, initial decrease was in fact exponential and that a linear fit to the initial part of this decrease, down to about $100 \mu \mathrm{M}$, could lead to an underestimation of the actual $\mathrm{O}_{2}$ uptake rate by 28 to $34 \%$. It is not known how large a problem this is in other studies.

\section{Regulation of oxygen uptake}

The experimental variation of $\mathrm{O}_{2}$ (Fig. 7) showed that the diffusive $\mathrm{O}_{2}$ uptake of the sediment was strongly dependent on $\mathrm{O}_{2}$ concentration in the overlying water, at least under short-term exposure to reduced $\mathrm{O}_{2}$. This observation may explain the small seasonal variation in $\mathrm{O}_{2}$ uptake, especially of the surficial oxic zone. The expected increase in $\mathrm{O}_{2}$ uptake due to settling of the spring phytoplankton bloom or due to the higher temperatures during summer was counteracted by reduced $\mathrm{O}_{2}$ concentration in the bottom water. This partial $\mathrm{O}_{2}$ depletion had 2 effects on the $\mathrm{O}_{2}$ flux: (1) it reduced the $\mathrm{O}_{2}$ gradient across the $\mathrm{DBL}$ thus reducing the diffusive flux (Fig. 7A) and (2) it reduced the thickness of the oxic zone by 3 -fold, thereby reducing the population of aerobic microorganisms which could respire with $\mathrm{O}_{2}$. Furthermore, the $\mathrm{O}_{2}$-depletion inactivated the bottom fauna and thus reduced their respiratory ventilation in the burrows.

It is not clear from the present results whether a long-term exposure to reduced $\mathrm{O}_{2}$ would gradually be compensated for by increased growth of the aerobic microbial populations closer to the sediment surface, or whether anaerobic mineralization would take over. The latter would result in the accumulation of reduced products, e.g. sulfide bound as $\mathrm{FeS}, \mathrm{FeS}_{2}$, or $\mathrm{S}^{\circ}$, which would subsequently require an equivalent amount of $\mathrm{O}_{2}$ for reoxidation to sulfate. The accumulation of such an 'oxygen debt' seems indeed to take place in Aarhus Bay sediments, especially during calm and warm periods. The reoxidation with $\mathrm{O}_{2}$ may occur during windy periods, often of short duration, when surface sediment is resuspended into the bottom water. Since this mechanism of rapid $\mathrm{O}_{2}$ consumption is not included in laboratory core incubations, the measured $\mathrm{O}_{2}$ uptake rates underestimate the total in situ rates by an unknown amount, at least when longer time-scales are considered.

The 300 to $400 \mu \mathrm{m}$ thick DBL had only little effect on the regulation of $\mathrm{O}_{2}$ uptake in Aarhus Bay sediments during winter (Fig. $7 \mathrm{C}$ ). Modeling of the $\mathrm{O}_{2}$ consumption at $100 \%$ air saturation in November (Fig. 7) yielded an uptake rate of $438 \mu \mathrm{mol} \mathrm{m}^{-2} \mathrm{~h}^{-1}$. In the absence of a $\mathrm{DBL}$, the calculated uptake rate would be $455 \mu \mathrm{mol} \mathrm{m} \mathrm{m}^{-2} \mathrm{~h}^{-1}$, given the same $\mathrm{O}_{2}$ consumption rate per unit volume. Thus, an impedance of the diffusion flux posed by the DBL limited the flux by $3.7 \%$. The general impedance by the DBL was 3 to $5 \%$ during winter, when the oxic zone was 4 to $5 \mathrm{~mm}$ thick, and 12 to $16 \%$ during summer, when it was 1.5 to $2 \mathrm{~mm}$ thick. Oxygen uptake of the sediment is thus mostly regulated by the internal diffusion regime (cf. Boudreau \& Guinasso 1982). In an in situ study of $\mathrm{O}_{2}$ microgradients in sediments of the Pacific shelf off 
the State of Washington, USA, Archer et al. (1989) found a DBL thickness averaging $1 \mathrm{~mm}$ and an oxic zone $5 \mathrm{~mm}$ deep. The authors calculated a limitation of the diffusive flux due to the DBL of about $10 \%$ relative to the case of no DBL.

\section{Seasonal dynamics of oxygen}

The seasonal variation in $\mathrm{O}_{2}$ uptake was small considering the 4 to $15^{\circ} \mathrm{C}$ temperature variation and the strong seasonal variation in primary productivity of Aarhus Bay. Other studies of sediment $\mathrm{O}_{2}$ uptake rates at similar latitudes have shown temperature variations with a $Q_{10}$ of 2 to 3 (Jørgensen 1977, Kanneworff \& Christensen 1986, Hall et al. 1989, Herndl et al. 1989). There was a significant increase in the diffusive $\mathrm{O}_{2}$ uptake, 345 to $504 \mu \mathrm{mol} \mathrm{m}{ }^{-2} \mathrm{~h}^{-1}$, in March-April 1988 in response to the settling of the spring phytoplankton bloom. Within the Baltic Sea and Kattegat area, a similar increase, from 330 to $540 \mu \mathrm{mol} \mathrm{m} \mathrm{m}^{-2} \mathrm{~h}^{-1}$, of $\mathrm{O}_{2}$ uptake in response to the spring bloom was observed in Laholms Bight on the east coast of Kattegat (Enoksson 1987). A strong stimulation of the benthic bacterial activity was also shown following sedimentation of the spring phytoplankton bloom in the Kiel Bight, Germany, (Graf et al. 1982), while no immediate effect was observed on respiration rates in Øresund sediment (Kanneworff \& Christensen 1986).

In spite of the limited seasonal variation in $\mathrm{O}_{2}$ uptake of the Aarhus Bay sediment, there was a strong seasonality in the intensity of $\mathrm{O}_{2}$ consumption within the oxic zone. Table 3 compares the situations during summer and before the spring bloom. The rate of $\mathrm{O}_{2}$ consumption in the thin oxic zone, calculated by modeling the $\mathrm{O}_{2}$ microgradients, was only 1.7 -fold higher during summer than during early spring. The oxic zone was much thinner during summer, however, $1.3 \mathrm{~mm}$ versus $5.1 \mathrm{~mm}$ as measured with the microelectrodes and $1.1 \mathrm{~mm}$ versus $5.5 \mathrm{~mm}$ as calculated from the $\mathrm{O}_{2}$ flux model (Eq. 7). The rate of $\mathrm{O}_{2}$ consumption per volume of sediment was thus

Table 3. Oxygen dynamics in oxic zone of Aarhus Bay sediment for 2 seasons

\begin{tabular}{|c|c|c|}
\hline Oxygen dynamics & $\begin{array}{c}\text { Aug/Sept } \\
1988\end{array}$ & $\begin{array}{l}\text { Mar } \\
1989\end{array}$ \\
\hline Modeled $\mathrm{O}_{2}$ uptake $\left(\mu \mathrm{mol} \mathrm{m} \mathrm{m}^{-2} \mathrm{~h}^{-1}\right)$ & 460 & 260 \\
\hline Measured depth of $\mathrm{O}_{2}$ zone (mm) & 1.3 & 5.1 \\
\hline Calculated depth of $\mathrm{O}_{2}$ zone $(\mathrm{mm})$ & 1.1 & 5.5 \\
\hline $\mathrm{O}_{2}$ uptake per vol. $\left(\mu \mathrm{mol} \mathrm{cm} \mathrm{cm}^{-3} \mathrm{~h}^{-1}\right)$ & 0.35 & 0.051 \\
\hline $\mathrm{O}_{2}$ pool in oxic zone $(\mu \mathrm{mol} \mathrm{m}-2)$ & 45 & 600 \\
\hline $\mathrm{O}_{2}$ turn-over time (h) & 0.10 & 2.3 \\
\hline
\end{tabular}

7 -fold higher during summer than during winter. The populations of aerobic microorganisms in the sediment therefore had a significant seasonality in their activity in spite of the rather constant areal $\mathrm{O}_{2}$ consumption.

The dynamics of $\mathrm{O}_{2}$ was also much more intensive during summer. Due to the low $\mathrm{O}_{2}$ concentration, the total $\mathrm{O}_{2}$ pool in the oxic zone of the sediment turned over within 6 min $(0.10 \mathrm{~h})$ during summer, while the turn-over time during early spring was $2.3 \mathrm{~h}$ (Table 3).

The thin oxic 'skin' of the sediment is a zone of extremely intensive respiration (per unit volume) as compared to the anaerobic respiration in anoxic layers below. Thus, following the sedimentation of the spring bloom, a zone of intensive sulfate reduction developed just below the oxic zone. Maximum reduction rates here reached $0.0026 \mu \mathrm{mol} \mathrm{SO}{ }_{4}^{-2} \mathrm{~cm}^{-3} \mathrm{~h}^{-1}$, which was equivalent to only $1.5 \%$ of the oxic respiration (calculated as carbon equivalents oxidized per $\mathrm{cm}^{3} \mathrm{~h}^{-1}$ ). When compared on an areal basis, however, the anaerobic processes increase strongly in significance as they occur in much thicker zones. The same comparison on an areal basis thus showed that sulfate reduction in the upper 0 to $10 \mathrm{~cm}$ of the sediment was equivalent to $35 \%$ of the $\mathrm{O}_{2}$ consumption (Moeslund, Thamdrup \& Jørgensen unpubl.).

Organic carbon is also mineralized rapidly in the oxic zone. The upper 0 to $2 \mathrm{~mm}$ of sediment had $770 \mu \mathrm{mol}$ org $\mathrm{C} \mathrm{cm}^{-3}$. Given the rates of $\mathrm{O}_{2}$ consumption in Table 3 , this organic $C$ could theoretically be mineralized by $\mathrm{O}_{2}$ within 3 months during summer, whereas the winter rates of $\mathrm{O}_{2}$ consumption would correspond to a mineralization over 2 yr.

When integrated over the whole year, the total $\mathrm{O}_{2}$ consumption of the sediment was $10.1 \mathrm{~mol} \mathrm{O}_{2} \mathrm{~m}^{-2}$. Primary production by plankton algae in the Aarhus Bay was about $200 \mathrm{~g} \mathrm{C} \mathrm{m}^{-2} \mathrm{yr}^{-1}$. This corresponds to $20 \mathrm{~mol} \mathrm{O}_{2} \mathrm{~m}^{-2} \mathrm{yr}^{-1}$ assuming a photosynthetic quotient of 1.2. The total sediment $\mathrm{O}_{2}$ uptake thus corresponded to the mineralization of half of the primary production of the area. To this should presumably be added the intermittent reoxidation by $\mathrm{O}_{2}$ of accumulated, reduced minerals during resuspension events.

Acknowledgments. We are grateful to Niels Peter Revsbech for his help and advise throughout this study and to Per Hall for critically reading the manuscript. We thank Birger Kruse for invitations to join 2 cruises onboard RV 'Gunnar Thorson' and Erik Lomstein for permission to use unpublished data. The study was supported by the Danish National Agency for Environmental Protection and the Danish Natural Science Research Council. 


\section{LITERATURE CITED}

Aller, R. C. (1978). Experimental studies of changes produced by deposit feeders on porewater, sediment, and overlying water chemistry. Am. J. Sci. 278: 1185-1234

Andersen, F. Ø., Helder, W. (1987). Comparison of oxygen microgradients, oxygen flux rates and electron transport system activity in coastal marine sediments. Mar. Ecol Prog. Ser. 37: 259-264

Andersson, L., Rydberg, L. (1988). Trends in nutrient and oxygen conditions within the Kattegat: effects of local nutrient supply. Estuar. coast. Shelf Sci. 26: 559-579

Archer, D., Emerson, S. Smith, C. R. (1989). Direct measurement of the diffusive sublayer at the deep sea floor using oxygen microelectrodes. Nature, Lond. 340: 623-626

Berner, R. A. (1980). Early diagenesis: a theoretical approach. Princeton University Press, Princeton, New Jersey

Booij, K. (1989). Exchange of solutes between sediment and water. Ph.D. thesis, Rijksuniversiteit Groningen

Boudreau, B. P. (1988). Mass-transport constraints on the growth of discoidal ferromanganese nodules. Am. J. Sci. 288: 777-797

Boudreau, B. P., Guinasso, N. L. Jr (1982). The influence of a diffusive sublayer on accretion, dissolution, and diagenesis at the sea floor. In: Fanning, K. A., Manheim, F. T. (eds.) The dynamic environment of the ocean floor. Lexington Books, Lexington, Massachusetts, p. 115-145

Bouldin, D. R. (1968). Models for describing the diffusion of oxygen and other mobile constituents across the mudwater interface. J. Ecol. 56: 77-87

Broecker, W. S., Peng, T.-H. (1974). Gas exchange rates between air and sea. Tellus 26: 21-35

Crank, J. (1983). The mathematics of diffusion. Clarendon Press, Oxford

Enoksson, V. (1987). Nitrogen flux between sediment and water and its regulatory factors in coastal areas. Ph.D. thesis, Univ. Gothenburg

Graf, G., Bengtsson, W., Diesner, U., Schulz, R., Theede, H. (1982). Benthic response to sedimentation of a spring phytoplankton bloom: process and budget. Mar. Biol. 67: $201-208$

Gundersen, J. K., Jørgensen, B. B. (1990). Microstructure of diffusive boundary layers and the oxygen uptake of the sea floor. Nature, Lond. 345: 604-607

Gundersen, J. K., Jørgensen, B. B. (1991). Fine-scale in situ measurements of oxygen distribution in marine sediments. Kieler Meeresforsch., Sonderh. 8: 376-380

Hall, P. O. J., Anderson, L. G., Rutgers van der Loeff, M. M., Sundby, B., Westerlund, S. F. G. (1989). Oxygen uptake kinetics in the benthic boundary layer. Limnol. Oceanogr. 34: $734-746$

Hao, O. J., Richard, M. G., Jenkins, D. (1983). The halfsaturation coefficient for dissolved oxygen: a dynamic method for its determination and its effect on dual species competition. Biotechnol. Bioeng. 25: 403-416

Herndl, G. J., Peduzzi, P., Fanuko, N. (1989). Benthic community metabolism and microbial dynamics in the Gulf of Trieste (Northern Adriatic Sea). Mar. Ecol. Prog. Ser 53: $169-178$

Hofman, P. A. G., de Jong, S. A., Wagenvoort, E. J., Sandee, A. J. J (1991). Apparent sediment diffusion coefficients for oxygen and oxygen consumption rates measured with microelectrodes and bell jars: applications to oxygen budgets in estuarine intertidal sediments (Oosterschelde, SW Netherlands). Mar. Ecol. Prog. Ser. 69: 261-272

Hüttel, M. (1988). The impact of macrofauna on nutrient con- centrations in pore water of intertidal sandflat sediments. Ph.D. thesis, No. 182, Christian-Albrechts Universität Kiel (in German)

Iversen, N., Jergensen, B. B. (in press). Diffusion coefficients of sulfate and methane in marine sediments: influence of porosity. Geochim. Cosmochim. Acta

Jørgensen, B. B. (1977). The sulfur cycle of a coastal marine sediment (Limfjorden, Denmark). Limnol. Oceanogr. 22: $814-832$

Jørgensen, B. B., Des Marais, D. J. (1990). The diffusive boundary layer of sediments: oxygen microgradients over a microbial mat. Limnol. Oceanogr. 35: 1343-1355

Jargensen, B. B., Revsbech, N. P. (1985). Diffusive boundary layers and the oxygen uptake of sediments and detritus. Limnol. Oceanogr. 30: 111-122

Kanneworff, E., Christensen, H. (1986). Benthic community respiration in relation to sedimentation of phytoplankton in the Øresund. Ophelia 26: 269-284

Kanneworff, E., Nicolaisen, W. (1973). The Haps, a framesupported bottom corer. Ophelia 10: 119-129

Kristensen, E. (1985). Oxygen and inorganic nitrogen exchange in a Nereis virens (Polychaeta) bioturbated sediment-water system. J. coast. Res. 1: 109-116

Li, Y.-H., Gregory, S. (1974). Diffusion of ions in sea water and in deep-sea sediments. Geochim. Cosmochim. Acta 38: $703-714$

Lindeboom, H. J., Sandee, A. J. J., De Klerk-van der Driessche, H. A. (1985). A new bell jar/micro electrode method to measure changing oxygen fluxes in illuminated sediments with a micro algal cover. Limnol. Oceanogr. 30 $693-698$

Mackin, J. E., Swider, K. T (1989). Organic matter decomposition pathways and oxygen consumption in coastal marine sediments. J. mar. Res. 47: 681-716

Nielsen, L. P., Christensen, P. B., Revsbech, N. P., Sorensen, J. (1990). Denitrification and oxygen respiration in biofilms studied with a microsensor for nitrous oxide and oxygen Microb. Ecol. 19: 63-72

Pamatmat, M. M. (1971). Oxygen consumption by the seabed. 4. Shipboard and laboratory experiments. Limnol Oceanogr. 16: $536-550$

Reimers, C. E., Smith, K. L. Jr (1986). Reconciling measured and predicted fluxes of oxygen across the deep sea sediment-water interface. Limnol. Oceanogr. 31: 305-318

Revsbech, N. P. (1989a). Diffusion characteristics of microbial communities determined by use of oxygen microsensors. J. microbiol. Meth. 9: 111-122

Revsbech, N. P. (1989b). An oxygen microsensor with a guard cathode. Limnol. Oceanogr. 34: 472-476

Revsbech, N. P., Jørgensen, B. B. (1983). Photosynthesis of benthic microflora measured with high spatial resolution by the oxygen profile method: capabilities and limitations of the method. Limnol. Oceanogr. 28: 749-756

Revsbech, N. P., Jorgensen, B. B., Blackburn, T. H. (1980a). Oxygen in the sea bottom measured with a microelectrode. Science 207 1355-1356

Revsbech, N. P., Madsen, B., Jargensen, B. B. (1986). Oxygen production and consumption in sediments determined at high spatial resolution by computer simulation of oxygen microelectrode data. Limnol. Oceanogr. 31: 293-304

Revsbech, N. P., Sørensen, J., Blackburn, T H., Lomholt, J. P. (1980b). Distribution of oxygen in marine sediments measured with microelectrodes. Limnol. Oceanogr. 25: $403-411$

Smith Jr, K. L. (1978). Benthic community respiration in the N. W. Atlantic Ocean: in situ measurements from 40 to 5200 m. Mar. Biol. 47: 337-347 
Svensson, U., Rahm, L. (1991). Toward a mathematical model of oxygen transfer to and within bottom sediments. J. Geophys. Res. 96: 2777-2783

Sweerts, J.-P. R. A. (1990). Oxygen consumption, mineralization and nitrogen cycling at the sediment-water intertace of north temperate lakes. Ph.D. thesis, Rijksuniversiteit Groningen

This article was submitted to the editor
Sweerts, J.-P. R. A., St. Louis, V., Cappenberg, T E. (1989). Oxygen concentration profiles and exchange in sediment cores with circulated overlying water Freshwat. Biol. 21: $401-409$

Ullman, W J., Aller, R. C. (1982). Diffusion coefficients in nearshore marine sediments. Limnol. Oceanogr. 27: $552-556$

Manuscript first received: December 27, 1991 Revised version accepted: March 16, 1992 